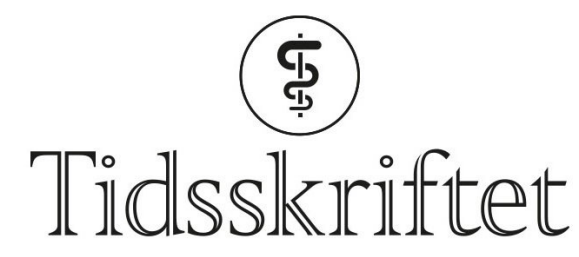

DEN NORSKE LEGEFORENING

\title{
Livet utenfor fakultetets vegger
}

TIDLIGERE I TIDSSKRIFTET

SYNNE LOFSTAD

E-post: synne.lofstad@hotmail.com

Redaksjonssjef i Æsculap

Blir man en god lege av å bare pugge på lesesalen, eller burde man også være sosial og ta seg en fest? Dette spørsmålet var allerede aktuelt i en debatt i 1930. Diskusjonen oppsto etter Medicinerforeningens (M. F.) beryktede 100-årsjubileum i 1929. Jubileet ble feiret med en fest som var så stor at den resulterte i en debatt om legers alkohol(mis)bruk og hva som burde være foreningens egentlige misjon (Æsculap 1930; 11: 1-2).

\section{Medisinerforeningen og „Æsculap”.}

Den diskusjon som blev åpnet i siste nummer av «Æsculap» før jul, fortsetter også i dette nummer. 


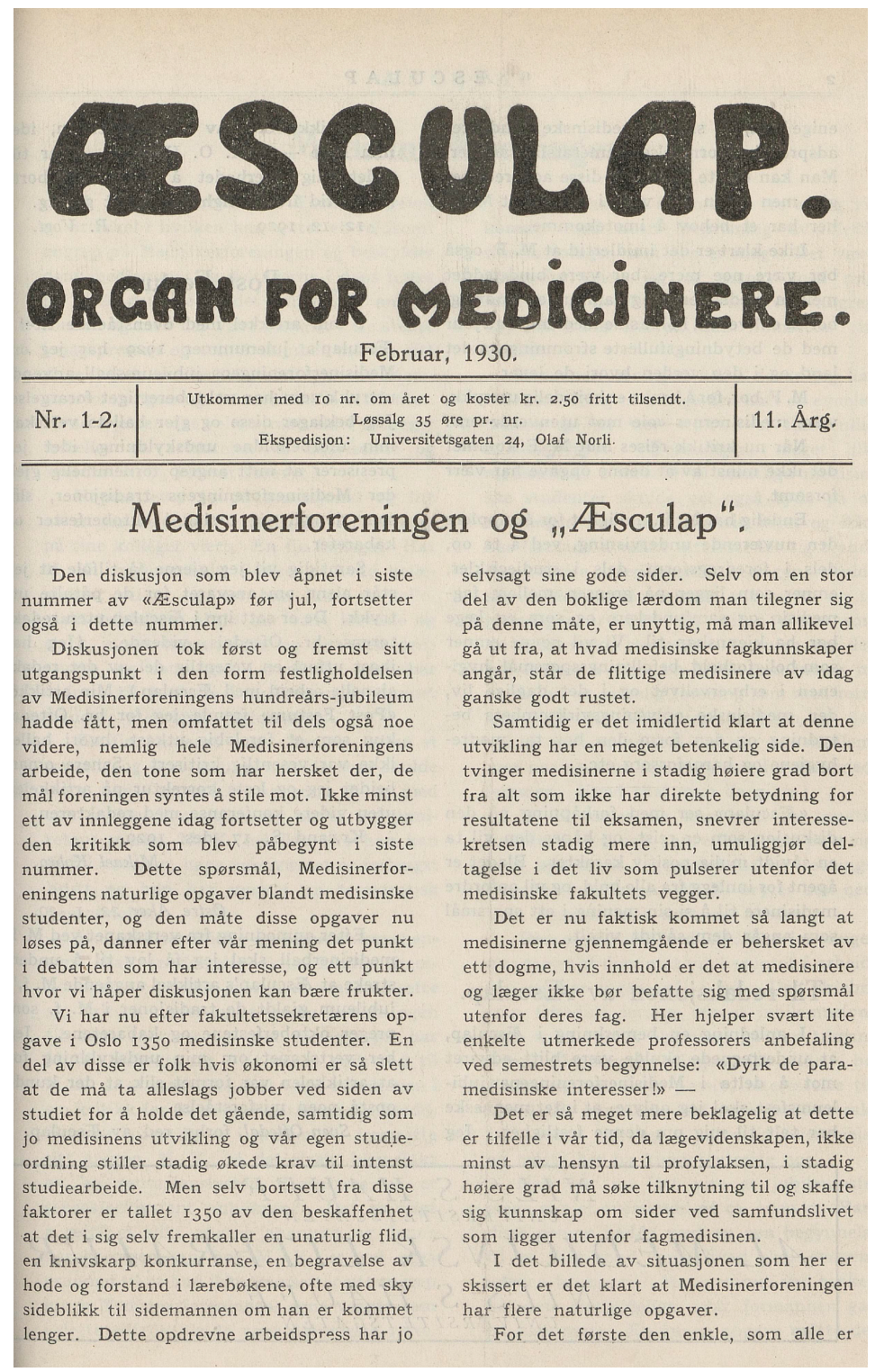

Diskusjonen tok først og fremst sitt utgangspunkt i den form festligholdelsen av Medisinerforeningens hundreårs-jubileum hadde fått, men omfattet til dels også noe videre, nemlig hele Medisinerforeningens arbeide, den tone som har hersket der, de mål foreningen syntes å stile mot. Ikke minst ett av innleggene idag fortsetter og utbygger den kritikk som blev påbegynt i siste nummer. Dette spørsmål, Medisinerforeningens naturlige opgaver blandt medisinske studenter, og den måte disse opgaver nu løses på, danner efter vår mening det punkt i debatten som har interesse, og ett punkt hvor vi håper diskusjonen kan bære frukter.

Vi har nu efter fakultetssekretærens opgave i Oslo 1350 medisinske studenter. En del av disse er folk hvis økonomi er så slett at de må ta alleslags jobber ved siden av studiet for å holde det gående, samtidig som jo medisinens utvikling og vår egen studieordning stiller stadig $\emptyset$ kede krav til intenst studiearbeide. Men selv bortsett fra disse faktorer er tallet 1350 av den beskaffenhet at det i sig selv fremkaller en unaturlig flid, en knivskarp konkurranse, en begravelse av hode og forstand i lærebøkene, ofte med sky sideblikk til sidemannen om han er kommet lenger. Dette opdrevne arbeidspress har jo selvsagt sine gode sider. Selv om en stor del av den boklige lærdom man tilegner sig på denne måte, er unyttig, må man allikevel gå ut fra, at hvad medisinske fagkunnskaper angår, står de flittige medisinere av idag ganske godt rustet.

En del av disse er folk hvis økonomi er så slett at de må ta alleslags jobber ved siden av studiet for å holde det gående

Samtidig er det imidlertid klart at denne utvikling har en meget betenkelig side. Den tvinger medisinere i stadig høiere grad bort fra alt som ikke har direkte betydning for 
resultatene til eksamen, snevrer interessekretsen stadig mere inn, umuliggjør deltagelse i det liv som pulserer utenfor det medisinske fakultetets vegger.

Det er nu faktisk kommet så langt at medisinere gjennemgående er behersket av ett dogme, hvis innhold er det at medisinere og læger ikke bør befatte sig med spørsmål utenfor deres fag. Her hjelper svært lite enkelte utmerkede professorers anbefaling ved semestrets begynnelse: «Dyrk de paramedisinske interesser!» -

Dette opdrevne arbeidspress har jo selvsagt sine gode sider

Det er så meget mere beklagelig at dette er tilfelle i vår tid, da lægevidenskapen, ikke minst av hensyn til profylaksen, i stadig høiere grad må søke tilknytning til og skaffe sig kunnskap om sider ved samfundslivet som ligger utenfor fagmedisinen.

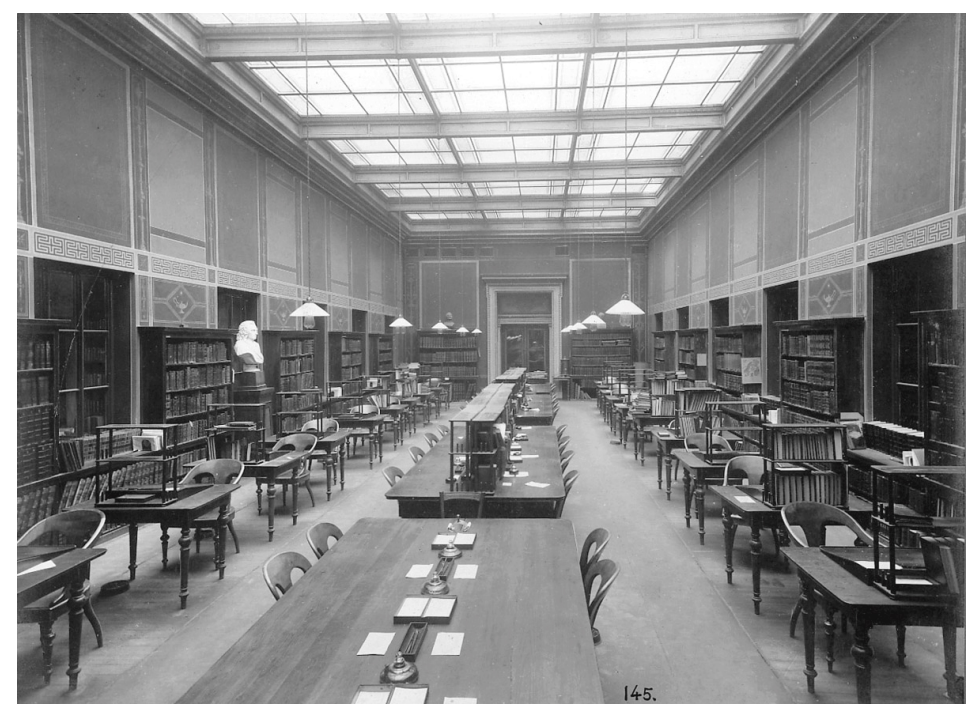

Lesesalen på universitetsbiblioteket. Foto: OlafMartin Peder Vering

I det billede av situasjonen som her er skissert er det klart at Medisinerforeningen har flere naturlige opgaver.

For det første den enkle, som alle er enige om, å skaffe medisinske studenter adspredelse, fornøielse, kameratslig samvær. Man kan drøfte den form disse adspredelser gis, men ingen kan være i tvil om at M. F. her har et behov å imøtekomme.

Like klart er det imidlertid at M. F. også bør være noe mere, bør være bindeleddet mellem medisinerne og samfundet forøvrig, bør til enhver tid holde sine medlemmer à jour med de betydningsfulleste strømninger i det land og i den verden hvori de lever.

M. F. bør, for å bruke et høitidelig uttrykk, være medisinernes «øie mot utenverdenen».

Når nu kritikk reises mot M. F. kommet det ikke minst av at denne opgave har værr forsømt.

M. F. bør, for å bruke et høitidelig uttrykk, være medisinernes «øie mot utenverdenen»

Endelig har M. F. mulighet for å supplere den nuværende undervisning, ved å ta op, dels i foredragsform, dels i studiecirkler, emner som ligger på grensen mellem fagmedisin og samfundslære og som en læge bør ha kjennskap til. Vi vil nevne emner som boligforhold, befolkningsspørsmål, hygienen i erhvervslivet og i det daglige liv, den medisinske oplysningsvirksomhets betydning og den form den før ta, mødrehygiene og barneforsorg etc.

«Æsculap» ser med forhåpning på den diskusjon som er reist, og håper den vil ta en såvidt mulig positiv karakter. Bladet er åpent for innlegg fra alle hold, og vil opfordre medisinere til å si sin mening i ett spørsmål som angår dem såvidt vitalt. 
(ㅇ) Tidsskrift for Den norske legeforening 2020. Lastet ned fra tidsskriftet.no 